\title{
Putative $\mathbf{N}_{2}$-fixing heterotrophic bacteria associated with dinoflagellate-Cyanobacteria consortia in the low-nitrogen Indian Ocean
}

\author{
Hanna Farnelid ${ }^{1}$, Woraporn Tarangkoon ${ }^{2,3}$, Gert Hansen ${ }^{4}$, Per Juel Hansen ${ }^{2}$, \\ Lasse Riemann ${ }^{1,5, *}$ \\ ${ }^{1}$ Department of Natural Sciences, Linnaeus University, 39182 Kalmar, Sweden \\ ${ }^{2}$ Section for Marine Biology, Strandpromenaden 5, 3000 Helsingør, Denmark \\ ${ }^{3}$ Faculty of Science and Fisheries Technology, Rajamangala University of Technology Srivijaya, 92150 Trang, Thailand \\ ${ }^{4}$ Department of Phycology, Ø. Farimagsgade 2D, 1353, Copenhagen, Denmark
}

${ }^{5}$ Present address: Section for Marine Biology, Strandpromenaden 5, 3000 Helsingør, Denmark

\begin{abstract}
Heterotrophic dinoflagellates bearing unicellular cyanobacterial symbionts are common within the order Dinophysiales. However, the ecological role of these symbionts is unclear. Due to the occurrence of such consortia in oceanic waters characterized by low nitrogen concentrations, we hypothesized that the symbionts fix gaseous nitrogen $\left(\mathrm{N}_{2}\right)$. Individual heterotrophic dinoflagellates containing cyanobacterial symbionts were isolated from the open Indian Ocean and off Western Australia, and characterized using light microscopy, transmission electron microscopy (TEM), and nitrogenase (nifH) gene amplification, cloning, and sequencing. Cyanobacteria, heterotrophic bacteria and eukaryotic algae were recognized as symbionts of the heterotrophic dinoflagellates. nifH gene sequences were obtained from 23 of $37(62 \%)$ specimens of dinoflagellates (Ornithocercus spp. and Amphisolenia spp.). Interestingly, only 2 specimens contained cyanobacterial nifH sequences, while 21 specimens contained nifH genes related to heterotrophic bacteria. Of the 137 nifH sequences obtained $68 \%$ were most similar to Alpha-, Beta-, and Gammaproteobacteria, $8 \%$ clustered with anaerobic bacteria, and $5 \%$ were related to second alternative nitrogenases (anfH). Twelve sequences from 5 host cells formed a discrete cluster which may represent a not yet classified nifH cluster. Eight dinoflagellates contained only 1 type of nifH sequence (>99\% sequence identity) but overall the putative $\mathrm{N}_{2}$-fixing symbionts did not appear host specific and mixed assemblages were often found in single host cells. This study provides the first insights into the nifH diversity of dinoflagellate symbionts and suggests a symbiotic co-existence of non-diazotrophic cyanobacteria and $\mathrm{N}_{2}$-fixing heterotrophic bacteria in heterotrophic dinoflagellates.
\end{abstract}

KEY WORDS: Symbionts · Nitrogen fixation $\cdot$ Nitrogenase $\cdot$ Heterotrophic bacteria $\cdot$ Ornithocercus . Amphisolenia · Histioneis · Dinoflagellates · Indian Ocean · Galathea 3

\section{INTRODUCTION}

Cyanobacterial symbionts (cyanobionts) of nonphotosynthetic dinophysoids (Dinophyceae) were first observed more than 100 yr ago (Schütt 1895). They are thought to function as photosynthetic partners in their relationship with the host (Taylor 1982), but despite many different types of cyanobacterial and bacterial symbionts having been described for several dinophysoid genera (such as Amphisolenia, Histioneis, Ornithocercus and Parahistioneis), little is known about the identity and diversity of these symbionts. Further, their ecological significance is essentially unknown.

Recently, we found that symbiont-bearing dinoflagellates were most common in the photic zone of the Indian Ocean characterized by low nutrients and low 
phytoplankton biomass (Tarangkoon et al. 2010). This is consistent with previous observations from the Indian Ocean (Jyothibabu et al. 2006) and the Red Sea (Gordon et al. 1994). Due to this distribution it has been suggested that the photosynthetic symbionts are $\mathrm{N}_{2}$ fixers (diazotrophs), providing their hosts with reduced N (Gordon et al. 1994, Jyothibabu et al. 2006). To date only a single study has demonstrated nitrogenase in a cyanobiont of a heterotrophic dinoflagellate (Foster et al. 2006a); however, several studies indicate that cyanobionts may be diazotrophic. For instance, even though most of the 65 cyanobacterial $16 S$ rRNA gene sequences retrieved from individual heterotrophic eukaryotic host cells were related to Synechococcus sp., 3 sequences from 2 Histioneis sp. hosts were related to the unicellular $\mathrm{N}_{2}$-fixing cyanobacterium Cyanothece sp. (Foster et al. 2006b). Further, using fluorescent in situ hybridization, putative unicellular diazotrophic cyanobionts associated with dinoflagellates have been observed in the Mediterranean Sea (Le Moal \& Biegala 2009) and the Southwest Pacific Ocean (Biegala \& Raimbault 2008).

In tropical and subtropical waters the ubiquitous filamentous cyanobacterium Trichodesmium sp. (Capone et al. 1997) and intracellular cyanobacterial symbionts of diatoms (Richelia intracellularis, a symbiont of diatoms, e.g. Rhizosolenia spp.; Carpenter et al. 1999) were long believed to be solely responsible for pelagic $\mathrm{N}_{2}$ fixation. However, recent molecular studies targeting the nitrogenase (nifH) gene, encoding the iron protein component of the nitrogenase enzyme, have shown that free-living unicellular cyanobacteria are also abundant and can account for a significant fraction of the $\mathrm{N}_{2}$ fixation (Zehr et al. 2001, Montoya et al. 2004). Similarly, it has recently been recognized that non-cyanobacterial diazotrophs, mostly heterotrophic bacteria, are widespread in marine waters, and their ecological function and importance is currently unknown (Farnelid \& Riemann 2008).

In the present study we sought to identify potential $\mathrm{N}_{2}$-fixing symbionts of heterotrophic dinoflagellates in the Indian Ocean. The symbionts were characterized using light microscopy and transmission electron microscopy (TEM) and nifH genes were amplified from individual symbiont-bearing dinoflagellate hosts using a nested PCR approach. Our study points to a hitherto unrecognized importance of heterotrophic bacteria for $\mathrm{N}$ acquisition in dinoflagellate-Cyanobacteria consortia in tropical waters.

\section{MATERIALS AND METHODS}

Sample collection. Sampling was carried out onboard the Danish Navy surveillance frigate 'F359
Vædderen' during Leg 7 of the 3rd Danish Galathea expedition (October to November 2006). Samples were obtained from 21 stations located across the Indian Ocean and along a transect perpendicular to Broome in North Western Australia (see Fig. 1 in Tarangkoon et al. 2010). For nifH gene analysis samples were obtained at stations BR5 to BR9 (BR5: $17^{\circ} 03^{\prime} \mathrm{S}$, $120^{\circ} 49^{\prime} \mathrm{E}_{;}$BR6: $16^{\circ} 50^{\prime} \mathrm{S}, 120^{\circ} 34^{\prime} \mathrm{E}_{\text {; }} \mathrm{BR7}: 1^{\circ} 26^{\prime} \mathrm{S}$, $119^{\circ} 56^{\prime} \mathrm{E}_{;}$BR8: $16^{\circ} 15^{\prime} \mathrm{S}, 1^{\circ} 19^{\circ} 38^{\prime} \mathrm{E}_{\text {; }}$ BR9: $16^{\circ} 01^{\prime} \mathrm{S}$ $119^{\circ} 19^{\prime} \mathrm{E}$ ) in the Broome transect. Live plankton samples were collected at each station by vertical hauls from about $70 \mathrm{~m}$ depth to the surface with a $20 \mu \mathrm{m}$ mesh size plankton net, or from water samples (30 l) from $10 \mathrm{~m}$ and $30 \mathrm{~m}$ depths collected by Niskin bottles attached to a conductivity, temperature and depth profiler rosette. Subsequently, plankton was concentrated using a $20 \mu \mathrm{m}$ mesh size Nitex filter. The filters were kept immersed during the filtration to facilitate the retention of live cells. The concentrated samples were transferred to $100 \mathrm{ml}$ of filtered seawater from which single cells were isolated using a drawn Pasteur pipette. Cells for nifH gene analysis were then successively washed in 3 baths of $2 \mathrm{ml} 0.2 \mu \mathrm{m}$ filtered seawater, placed individually in a $0.2 \mathrm{ml}$ PCR tube, and immediately frozen at $-20^{\circ} \mathrm{C}$. The cells included a range of dinoflagellate species (see Table 3 ), although no Histioneis spp. were obtained.

Microscopy. Dinoflagellates were examined shortly after sampling using an Olympus BX51 light microscope fitted with a Soft-Imaging ColorView III digital camera and identified as described in Tarangkoon et al. (2010). In total $\sim 100$ cells were examined in the study. Seven cells of Ornithocercus magnificus and 2 of $O$. quadratus were collected at Stn 5 in the Indian Ocean transect $\left(29^{\circ} 35^{\prime} \mathrm{S}, 9^{\circ} 15^{\prime} \mathrm{E}\right)$, preserved and further processed in the laboratory for TEM (Tarangkoon et al. 2010). Briefly, sections performed on an Ultracut E ultramicrotome using a diamond knife were collected on slot grids, placed on Formvar film, and stained in uranyl acetate and lead citrate. The sections were examined in a JEOL JEM-1010 electron microscope operated at $80 \mathrm{kV}$ and micrographs were taken using a GATAN 792 digital camera.

DNA extraction and nifH amplification. DNA was extracted from individual heterotrophic dinoflagellates with symbionts using an enzyme/phenol-chloroform protocol (Riemann et al. 2008) and $200 \mu \mathrm{l}$ SET lysis buffer (20\% sucrose, 50 mM EDTA, 50 mM Tris$\mathrm{HCl}, \mathrm{pH}$ 8.0). An extraction without added sample served as a control on the purity of the extraction chemicals. Seven of the samples were not subjected to the extraction procedure but to 3 cycles of freeze/ thawing $\left(-80^{\circ} \mathrm{C}\right.$ for $1 \mathrm{~min}$ and $75^{\circ} \mathrm{C}$ for $1 \mathrm{~min}$ constituted 1 cycle), which lyses the cells (Sebastian \& O'Ryan 2001). To amplify nifH, degenerate primers 
purified by high performance liquid chromatography and polyacrylamide gel electrophoresis (SigmaAldrich; Zehr \& McReynolds 1989, Zani et al. 2000) were used according to a nested PCR protocol (Zehr \& Turner 2001) using Pure Taq Ready-To-Go PCR Beads (GE Healthcare). A negative control reaction with UV-treated water was included in each PCR batch. To minimize the risk of contamination, mixing of reagents was done in a UV-treated sterile flow bench in a UV-treated room, template was added in a PCR/UV workstation in a separate room, and single tubes (not strips) were used. For the initial PCR reaction, 3 to $6 \mu \mathrm{l}$ of the extracted DNA or freeze/thawed solution was added as template and $1 \mu \mathrm{l}$ PCR product was transferred to the subsequent PCR reaction. Five $\mu l$ from the second PCR reaction was examined on a $1 \%$ agarose gel, and for samples that produced a $\sim 359 \mathrm{bp}$ product the remaining $20 \mu \mathrm{l}$ was gel purified (E.Z.N.A Gel extraction kit, VWR). The negative PCR control and the negative extraction control were always blank. For the negative control PCR reaction, although there was no visible product, the gel region corresponding to the correct product size was excised, gel purified and cloned. All purified products were cloned using the TOPO TA Cloning Kit (Invitrogen). Plasmid DNA was obtained using the R.E.A.L Prep96 Plasmid Kit (Qiagen) according to manufacturer's protocol and sequencing was done commercially (Macrogen, Korea).

Sequence and phylogenetic analysis. Vector sequences and primers were removed manually and the sequences were translated and aligned using the Lasergene 7 package (DNASTAR). The most similar uncultured and cultured relatives as identified from BLASTN comparisons from the NCBI GenBank database were added to the dataset and a neighbor-joining phylogenetic tree was constructed in MEGA4 (Tamura et al. 2007). The partial nifH sequences have been deposited in GenBank under accession numbers GU196835 to GU196971.

\section{RESULTS}

\section{Microscopy analyses of symbionts}

The morphologies (e.g. color, shape and size) of symbionts of heterotrophic dinoflagellates ( 100 cells) were compared to published data on ectosymbionts (Table 1) and endosymbionts (Table 2). All Ornithocercus spp. cells had orange and elongated cyanobacterial ectosymbionts located within the cingulum, while some also had large rod-shaped non-cyanobacterial prokaryotes on their sulcal lists (Fig. 1A, Table 1). Histioneis spp. contained 2 other types of cyanobacterial ectosymbionts (Fig. 1B, Table 1). In Amphisolenia spp. only endosymbiotic spheres of 3 to $7 \mu \mathrm{m}$ were found (Fig. 1C, Table 2). The endosymbionts in A. bidentata contained a single yellow chloroplast and a nucleus demonstrating its eukaryotic origin. The symbionts of A. thrinax had a more brownish color, but whether these symbionts were of a eukaryotic origin is unclear (not shown).

TEM revealed that the ectosymbionts of Ornithocercus magnificus and O. quadratus were Cyanobacteria and heterotrophic bacteria (Fig. 2A). Cyanobacterial ectosymbionts were observed in the cingulum of both species (Fig. 2A), though most were lost during the preparation process for TEM. These all appeared to be of the same type, i.e. containing 1 to 3 peripheral thylakoid bands in addition to several bands traversing the cell (Fig. 2B,E). Clusters of polyhedral granules, carboxysomes (Lucas 1991), were present in all the cyanobacterial ectosymbionts examined (Fig. 2B,D). In some, electron translucent granules were present (Fig. 2E), similar to putative cyanophycin granules (Lucas 1991). A typical eubacterial Gram-negative wall, consisting of a thin wall inbetween 2 membranes, surrounded the cyanobiont cells (Fig. 2C). Small rodshaped, $1.5 \times 0.2 \mu \mathrm{m}$, heterotrophic bacteria were observed in the cingulum of some Ornithocercus cells (Fig. 2A,F,G). Unfortunately, the large rod-shaped heterotrophic bacteria seen on the sulcal list by light microscopy (Fig. 1A) were lost during the TEM preparation procedure.

\section{nifH sequence composition and phylogeny}

nifH amplicons were obtained from 23 of the 37 analyzed symbiont-bearing heterotrophic dinoflagellates. The 137 nifH sequences obtained were related to nifH Cluster I (Cyanobacteria and Alpha-, Beta-, and Gammaproteobacteria), Cluster II (alternative nitrogenases; anfH) and Cluster III (anaerobic bacteria) as defined by Chien \& Zinder (1996). Sixty-eight percent of the sequences (originating from 17 samples) were most similar to proteobacterial nifH sequences (Fig. 3). All 10 sequences from the negative control formed a cluster within Betaproteobacteria (>98\% within-cluster sequence identity, Fig. 3) related to a previously reported PCR reagent contaminant sequence. Four sample sequences (A. bidentata, samples P60 and P62, Table 3) were affiliated with this cluster, but were not identical to the negative control sequences. Other sequences clustering with Betaproteobacteria were most similar to Ideonella dechloratans (18 sequences from 5 samples; 91 to $92 \%$ sequence identity) and Burkholderia vietnamiensis (12 sequences from 5 samples; 97 to $98 \%$ 


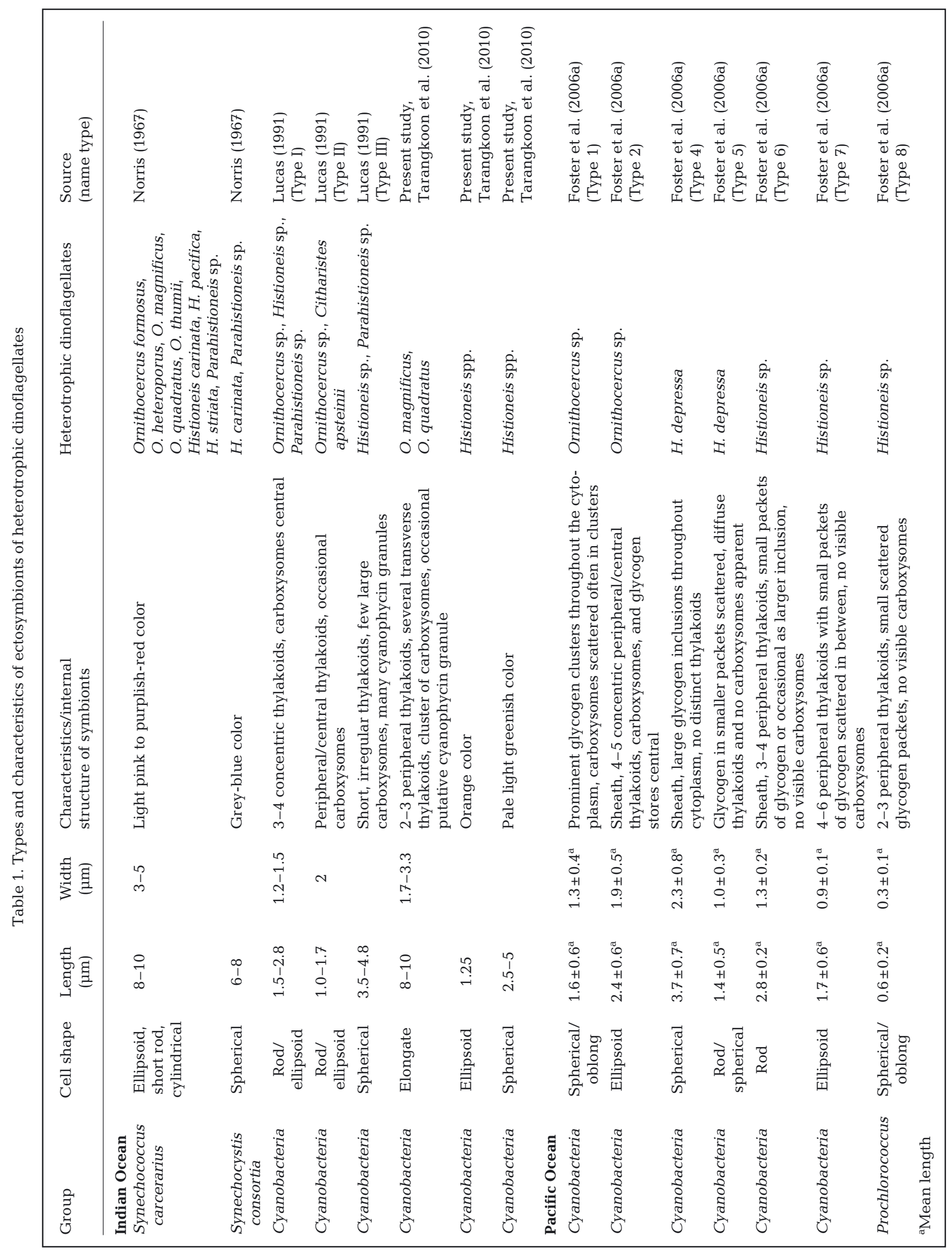



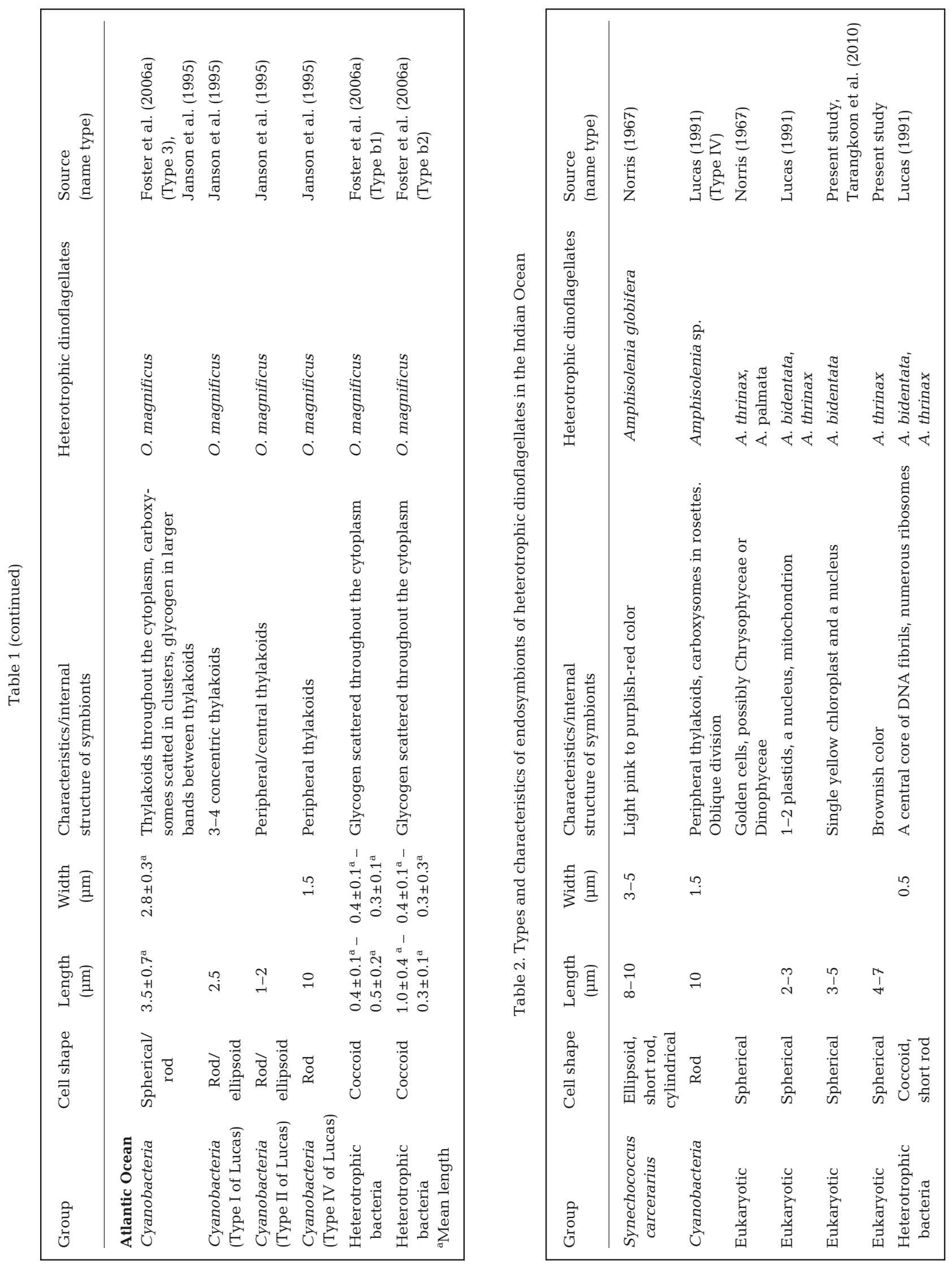


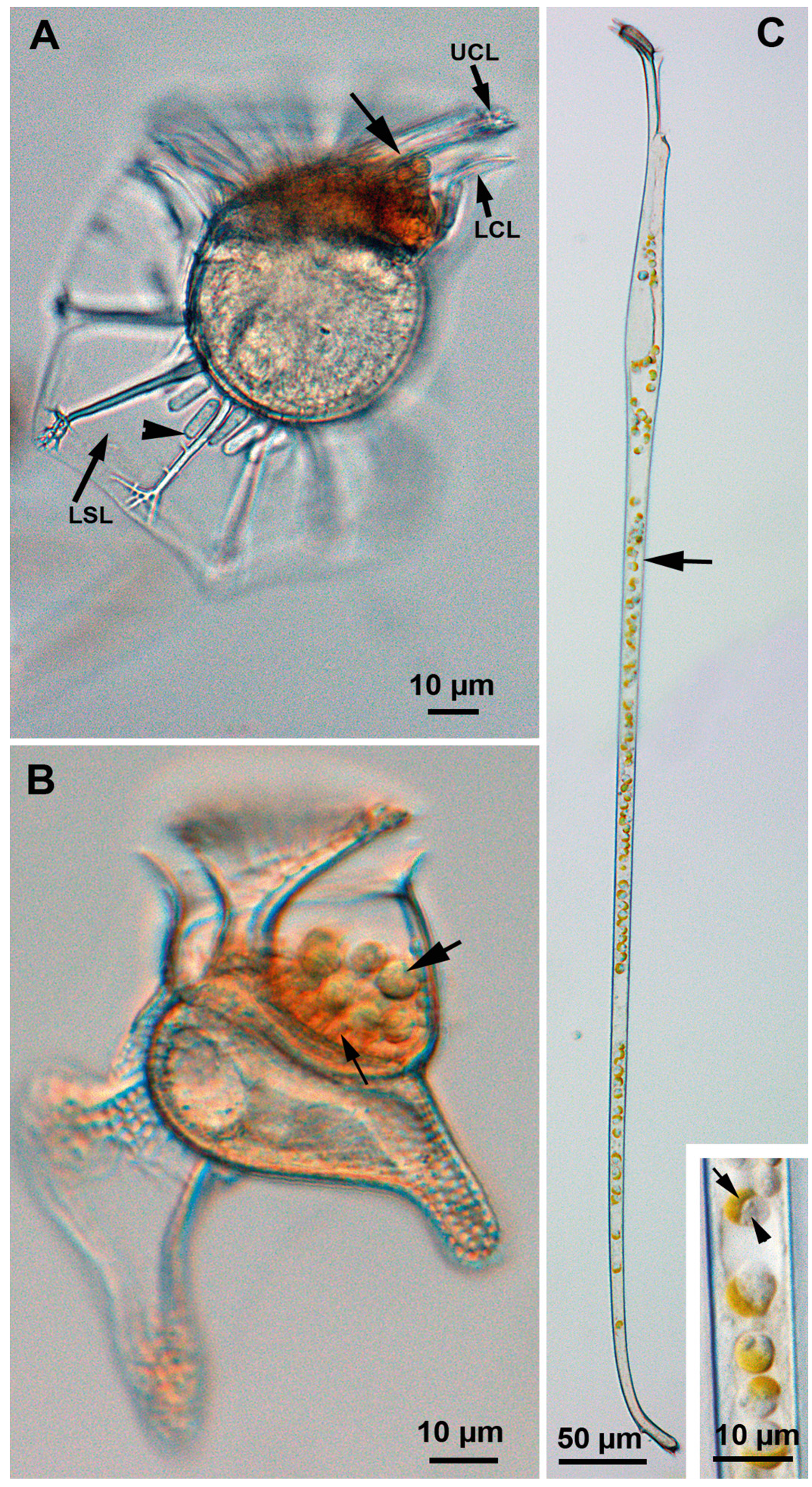

Fig. 1. Light microscopy of live cells. (A) Ornithocercus thumii; cyanobacterial ectosymbionts (large arrow). Notice large bacteria on the sulcal list (arrowhead). Small arrows indicate LCL (lower cingular list), UCL (upper cingular list), LSL (left sulcal list). (B) Histioneis biremis; 2 different types of cyanobacterial ectosymbionts are present (large and small arrow, respectively). (C) Amphisolenia bidentata with numerous eukaryotic endosymbionts (arrow). Inset: Details of the endosymbionts. Chloroplast (arrow), nucleus (arrowhead) sequence identity) but were clearly distinguished from the negative control sequences $\quad(<89 \%$ sequence identity, $<96 \%$ amino acid similarity, Fig. 3).

Two of the dinoflagellates contained nifH sequences clustering with Cyanobacteria (Fig. 3). Sample P7 contained sequences of $97 \%$ sequence identity to Nostoc punctiforme while the sequences from P1 were only distantly related to known phylotypes (<78\% sequence identity). Three samples contained nifH sequences within nifH Cluster III and 2 samples contained sequences related to anfH genes, encoding the iron-only nitrogenase, within nifH Cluster II (Table 3). Twelve sequences, originating from 5 samples, formed a well supported cluster (bootstrap 99\%, Fig. 3), which may represent a novel nifH cluster. These sequences clustered with Caldicellulosiruptor saccharolyticus (87 to $98 \%$ sequence identity) and with environmental nifH sequences (EU978414 and EU693383). Five sequences formed a separate cluster only distantly related to known nifH phylotypes (<69\% sequence identity, Fig. 3).

To link sequence composition to dinoflagellate hosts, we examined whether a sample contained single or several nifH sequence types and whether specific nifH sequences were associated with specific host species. Eight host cells, among which all examined host species were represented, contained only 1 nifH sequence type (>99\% sequence identity) while 9 host cells contained 2 or 3 nifH sequence types each (Table 3 ). In addition, similar nifH sequences were found in several hosts and different host species (Fig. 3). For example, 13 nifH gammaproteobacterial sequences from 4 samples of different species formed a distinct cluster with an uncultured nifH phylotype from the Pacific Ocean (DQ481270, 98 to $99 \%$ sequence identity) and 13 sequences originating from 3 samples of different species clustered with Klebsiella pneumoniae (98 to $99 \%$ sequence identity). 

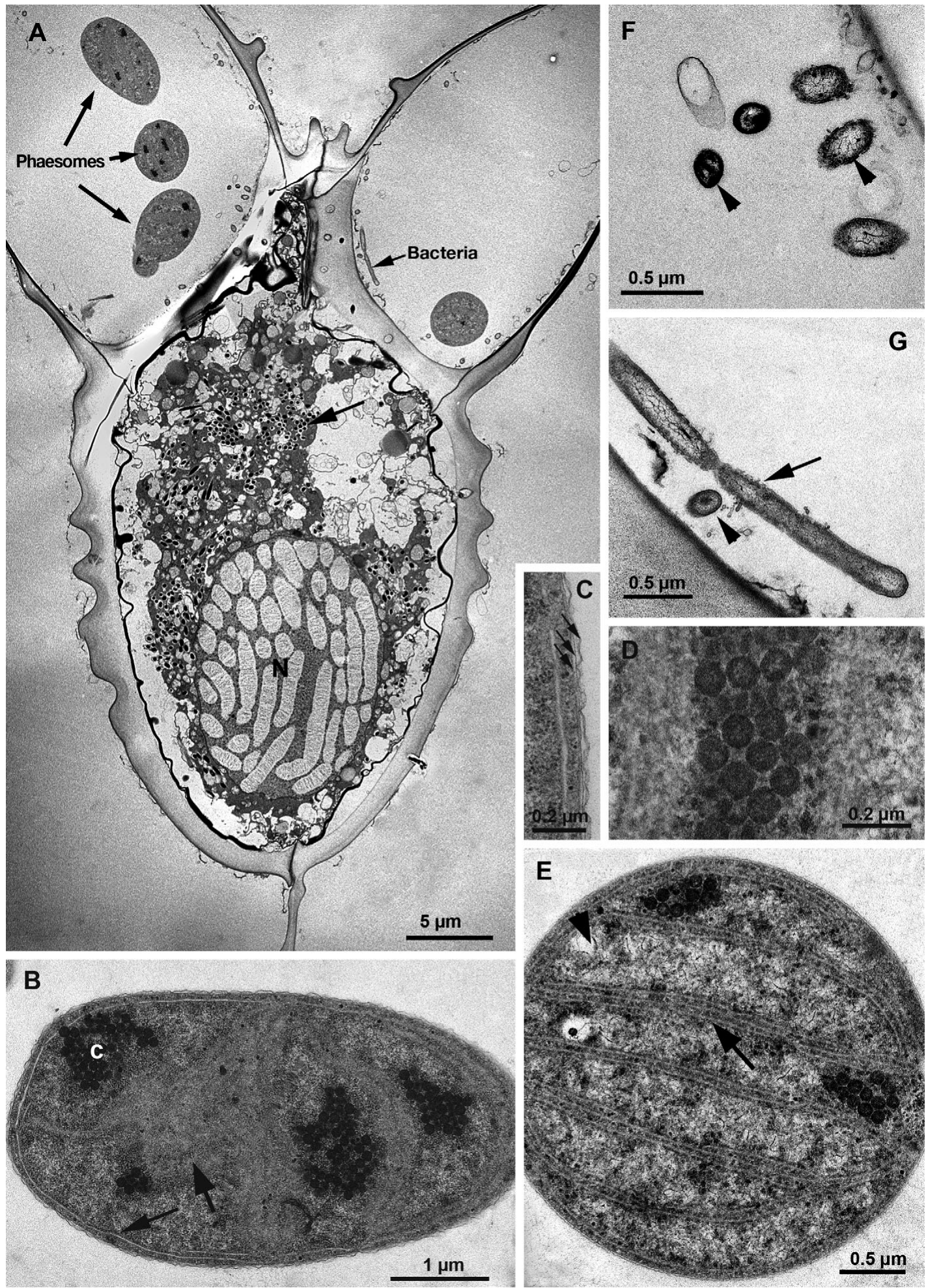

Fig. 2. TEM of Ornithocercus magnificus. (A) Longitudinal section of whole cell of $O$. magnificus. Four cyanobacterial ectosymbionts and small bacteria are present in the cingulum (large and small arrows, respectively). Numerous rhabdosomes are present within the cell (arrowhead). (B) Longitudinal section of a cyanobiont. Peripheral (small arrow) and central thylakoid membranes (large arrow); putative carboxysomes (c). (C) The triple-layered cyanobiont wall (arrows). (D) The putative carboxysomes. (E) Traversing thylakoids (arrow) and putative cyanophycin granule (arrowhead) of a cyanobiont. (F, G) Details of the bacterial ectosymbionts, in longitudinal (arrow) and transverse view (arrowhead) 


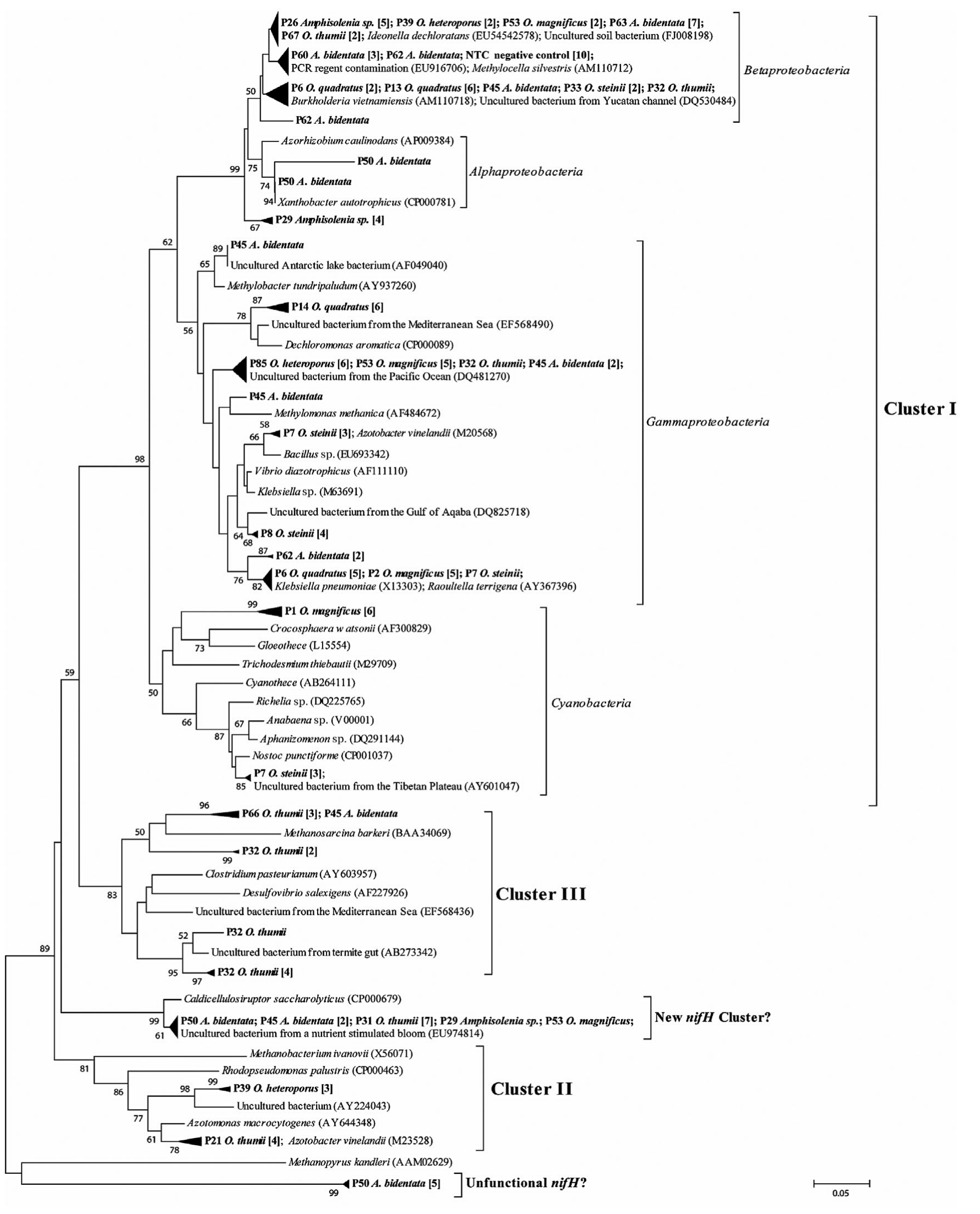

Fig. 3. Neighbor-joining phylogenetic tree of nifH-deduced amino acid sequences from symbiont-bearing heterotrophic dinoflagellates. Bootstrap values $>50 \%$ (1000 replications) are shown. Scale indicates the number of amino acid substitutions per site. Multiple sequences clustering together are collapsed into triangles. Sample number and the individual host with symbionts are indicated in bold with the number of sequences in square brackets. Reference sequences are given with GenBank accession numbers in parentheses. A.: Amphisolenia; O.: Ornithocercus 
Table 3. Phylogenetic affiliations of the nitrogenase gene (nifH) sequences obtained from various dinoflagellate species. The \% sequence identity among the sequences clustering together is indicated in parentheses after the number of sequences per cluster. The nifH Cluster (I to III) is also given alongside the phylogenetic affiliation in parentheses ( $\alpha$ : Alphaproteobacteria, $\beta$ : Betaproteobacteria,

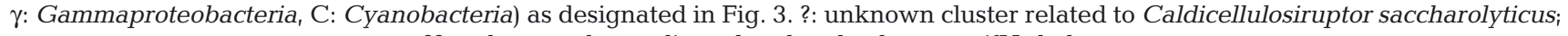
??: unknown cluster distantly related to known nifH phylotypes

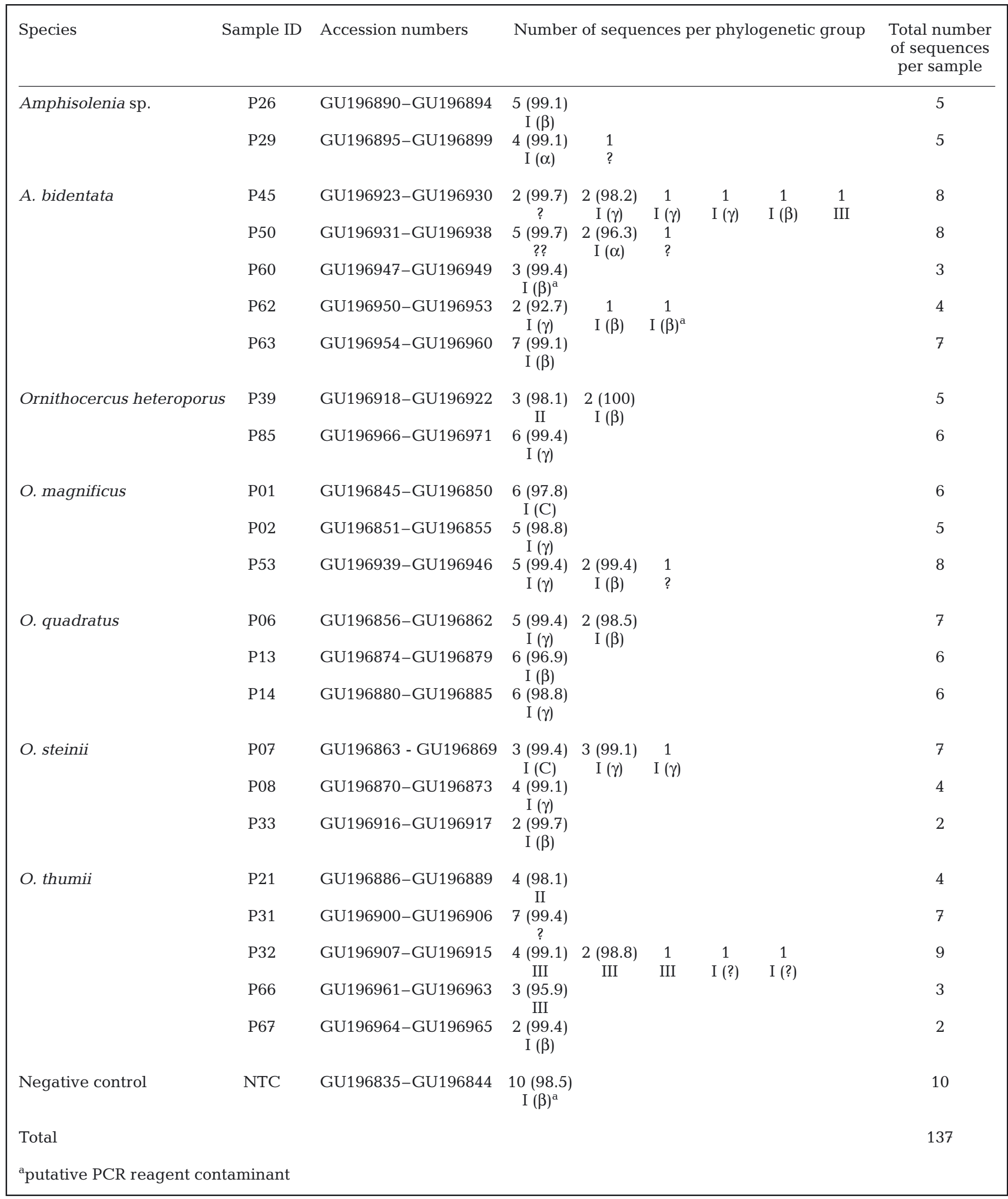




\section{DISCUSSION}

The role of heterotrophic dinoflagellate symbionts has been a mystery for many years. Due to the apparent restriction of these consortia to marine waters deplete of inorganic reduced $\mathrm{N}$, it has been suggested that the cyanobacterial symbionts provide their hosts with $\mathrm{N}$ through $\mathrm{N}_{2}$ fixation (Gordon et al. 1994, Jyothibabu et al. 2006, Tarangkoon et al. 2010). In this first report of nifH genes from dinoflagellate-Cyanobacteria consortia, we show that 23 of the 37 investigated dinoflagellate cells carried putative diazotrophs, and that 21 of these carried nifH genes exclusively related to heterotrophic bacteria. Hence, our analysis suggests that heterotrophic diazotrophs rather than Cyanobacteria supply the dinoflagellates with reduced $\mathrm{N}$.

\section{Identification of symbionts through microscopy}

The identification of symbionts of heterotrophic dinoflagellates has so far primarily been based on size, shape, pigmentation, and in some cases, ultrastructure. Heterotrophic bacterial ectosymbionts and/or cyanobacterial ectosymbionts of heterotrophic dinoflagellates have been described from the Indian, Pacific and Atlantic Oceans (Table 1). The types of ectosymbionts that we observed are similar to those previously described from the Indian Ocean (Table 1). For instance, the fairly large ectosymbionts $(8-10 \times 3-5 \mu \mathrm{m})$ in Ornithocercus magnificus and $O$. quadratus were similar in pigmentation, size and shape to Synechococcus carcerarius (Norris 1967; our Table 1). This was supported by a molecular study targeting cyanobacterial $16 S$ rRNA gene sequences from symbionts of eukaryotic hosts where the majority of the cyanobacterial sequences were closely related to Synechococcus (>96\% similarity; Foster et al. 2006b). Further, the ectosymbionts of Histioneis carinata and $H$. biremis both contained at least 2 types of reddish cyanobacterial ectosymbionts; a large one (2.5 to $5 \mu \mathrm{m})$ and a smaller one (1.25 $\mu \mathrm{m}$, Fig. 1B), similar to Types III and I, respectively (Table 2 in Lucas 1991).

In accordance with previous observations from the Indian Ocean, we found cyanobacterial and eukaryotic endosymbionts in Amphisolenia spp. (our Table 2; Tarangkoon et al. 2010). Photosynthetic endosymbionts were observed in both $A$. bidentata (Fig. 1C) and $A$. thrinax. So far only one type of prokaryotic endosymbiont, $S$. carcerarius, has been reported; originating from A. globifera (Norris 1967, Hallegraeff \& Jeffrey 1984, Lucas 1991), while eukaryotic endosymbionts have been reported from different species of Amphisolenia (Norris 1967, Lucas 1991). We observed an additional type of eukaryotic symbiont in A. bidentata.
Interestingly, Foster et al. (2006b) also recovered $16 S$ $r R N A$ genes $<92 \%$ identical to eukaryotic plastids from an $A$. bidentata host, which could represent the eukaryotic symbionts as reported by Lucas (1991) and/or in this study (Table 2)

Heterotrophic bacteria have previously been reported as both ecto- and endosymbionts of heterotrophic dinoflagellates (Tables 1 \& 2). For instance, Foster et al. (2006a) detected 2 morphotypes of heterotrophic bacteria associated with Ornithocercus magnificus. Likewise, we observed heterotrophic bacterial ectosymbionts of Ornithocercus spp. (Fig. 1A) and both cyanobacterial and heterotrophic bacterial ectosymbionts for O. magnificus and O. quadratus (Fig. 2A). In O. magnificus and O. steinii, Janson et al. (1995) observed heterotrophic bacteria between the upper and the lower girdle list of the cingular groove in all samples examined by TEM. Also, groups of heterotrophic bacterial endosymbionts have been observed in the cytoplasm of A. thrinrax and A. bidentata (Lucas 1991). Interestingly, although using primers targeting cyanobacteria, $26 \%$ of the $16 S$ rRNA sequences recovered from eukaryotic marine hosts by Foster et al. (2006b) originated from heterotrophic bacteria; however, none of these could be directly linked to diazotrophic species (based on BLASTN search results on unpublished sequences provided by R. A. Foster). Thus, the occurrence of heterotrophic ecto- and endosymbionts of heterotrophic dinoflagellates is not unusual but to our knowledge, there has been no previous documentation of a $\mathrm{N}_{2}$-fixing potential in these symbionts.

\section{Identities of nifH genes obtained from symbiont-bearing dinoflagellates}

Although cyanobacterial symbionts were visible in all examined dinoflagellates, only 2 of the 23 cells, which yielded nifH sequences, had sequences related to Cyanobacteria. Intriguingly, sample P7 (Ornithocercus steinii) contained nifH sequences of $97 \%$ sequence identity with the filamentous heterocystous cyanobacterium Nostoc punctiforme, which is known from freshwater and for its endosymbiotic associations with plants (Meeks et al. 2002). Similarly, 16S rRNA gene sequences $92 \%$ identical to Nostoc spp. were found in an Amphisolenia bidentata host (Foster et al. 2006b). Taken together, these results may suggest that symbiosis facilitates the survival of Nostoc spp. in the saline marine environment. nifH sequences related to Cyanobacteria were also obtained from sample P1 (O. magnificus) but these were only distantly related to known phylotypes (Fig. 3). Since very few nifH sequences related to Cyanobacteria were found, we find it unlikely that the role of the Cyanobacteria in the 
symbiosis should be to supply the host with reduced N. Importantly, in a parallel study (F. Farnelid \& L. Riemann unpubl.) using the same primer sets, we detected representatives from the major groups of unicellular Cyanobacteria (e.g. Crocosphaera watsonii, Cyanothece sp. and Group A; Bergman et al. 1997, Stal \& Zehr 2008). Thus, the lack of these known Cyanobacteria in the present data set is not due to a primer mismatch.

Twenty-one samples contained sequences clustering in nifH Cluster I, with Alpha-, Beta-, and Gammaproteobacteria (Fig. 3, Table 3). nifH gene contamination of PCR reagents, particularly with alpha- and betaproteobacterial sequences, may occur in the nested PCR (Zehr et al. 2003, Goto et al. 2005). However, the 10 nifH sequences we obtained from non-visible negative control samples clustered with only 4 sample sequences (Fig. 3, Table 3) and were not identical to any sample sequences. Hence, reagent contamination appeared negligible in the present study. However, hypothetical sources of error such as amplification of nifH genes derived from bacteria ingested by the host or from free-living bacteria which may have been passed through the 3 washing steps with $0.2 \mu \mathrm{m}$ filtered seawater cannot be ruled out. In addition, as the detection limit of the nested nifH assay is unknown, samples which did not yield a nifH product could theoretically have contained putative diazotrophs.

Diverse Proteobacteria within nifH Cluster I are commonly detected in marine waters (e.g. Zehr et al. 1998, Church et al. 2005, Langlois et al. 2005, Hewson et al. 2007 Moisander et al. 2008). Associated with dinoflagellates, we found 8 diverse clusters of nifH sequences related to Gammaproteobacteria while only 2 sequences were related to Alphaproteobacteria (Fig. 3). Interestingly, 30 sequences (22\% of all sequences) were affiliated with 2 betaproteobacterial clusters, distinct from the negative control sequences (Fig. 3). Similarly, bacteria associated with the photosynthetic dinoflagellate Gyrodinium instriatum were dominated by Betaproteobacteria (Alverca et al. 2002). Hence, although rare in marine ecosystems (Barberán \& Casamayor 2010), Betaproteobacteria appear common as symbionts of dinoflagellates.

Sequences clustering in nifH Cluster II were obtained from 2 samples (Ornithocercus heteroporus P39 and $O$. thumii P21, Table 3). Molybdenum-independent nitrogenases are present in a diverse group of diazotrophs and second alternative nitrogenases are expressed under molybdenum- and vanadium-deficient conditions (Betancourt et al. 2008). Bacteria containing alternative nitrogenase genes have been isolated from diverse marine environments (Loveless et al. 1999) but interestingly, anfH related genes seem to be absent in sub-tropical and tropical open waters (e.g. Zehr et al. 1998, Church et al. 2005, Langlois et al. 2005, Hewson et al. 2007, Moisander et al. 2008). Thus, the recovery of anfH related genes suggests that symbionts of dinoflagellates may be an environmental niche in open water where second alternative nitrogenase genes can be used.

Sequences from Cluster III, which contains nifH genes from anaerobic bacteria, have been detected (Church et al. 2005) but appear uncommon in the open ocean (Langlois et al. 2005, 2008). The presence of Cluster III sequences in 3 dinoflagellates therefore suggests that the dinoflagellate-Cyanobacteria consortia provide low oxygen $\left(\mathrm{O}_{2}\right)$ habitats required for $\mathrm{N}_{2}$ fixation (Paerl \& Prufert 1987). Similarly, Cluster III sequences from strict anaerobes and nitrogenase activity have been detected in association with zooplankton (Braun et al. 1999). However, since our Cluster III sequences were only distantly related to cultivated anaerobic bacteria (76 to $87 \%$ sequence identity), the phenotypes they represent are rather uncertain. Survival of strict anaerobes associated with dinoflagellates would presumably require vertical inheritance of these symbionts as the dinoflagellate host divides. However, given the observed non-host specificity for the symbionts (see below), it may be more likely that the obtained Cluster III sequences derive from facultatively anaerobic bacteria.

Twelve sequences originating from 5 samples formed a discrete nifH cluster separate from the known nifH Clusters I to IV (Chien \& Zinder 1996; our Fig. 3). These sequences had a sequence identity of 87 to $98 \%$ to the nifH gene of Caldicellulosiruptor saccharolyticus (van de Werken et al. 2008), which can grow in the absence of reduced $N$ (van Niel et al. 2002). It is surprising to find sequences closely related to an anaerobic extreme thermophile in the pelagic zone; however, the cluster also contains nifH sequences from a marine bloom and from symbionts of corals. Hence, surfaceassociated growth in the marine environment, such as in association with dinoflagellates, may be characteristic for these bacteria.

Eleven clone libraries yielded 2 or 3 different nifH sequence types per dinoflagellate. This suggests the presence of mixed assemblages of diazotrophic symbionts in host cells (Table 3), consistent with previous microscopy observations of mixed populations of cyanobionts and/or bacterial cell types in one host cell (Foster et al. 2006a). In addition, observations of several specimens of the same dinoflagellate species with diverging nifH sequences and different species of dinoflagellates hosting identical nifH sequences suggested that the nifH phylotypes were not host specific. Similar patterns of non-host specific 16S rRNA gene phylotypes were also observed for cyanobacterial sym- 
bionts in tintinnids, dinoflagellates, and radiolarians (Foster et al. 2006b). In contrast, in the Richelia intracellularis-diatom symbiosis a divergence of het $R$ and nifH sequences of symbionts from different host genera was interpreted as an indication of host specificity (Janson et al. 1999, Foster \& Zehr 2006). Thus, it appears that at any one time dinoflagellate hosts may contain multiple symbionts but the low degree of specificity also indicates that their dependence on specialized symbionts is not fundamental.

\section{Putative ecological roles of the consortia}

In dinoflagellate-Cyanobacteria consortia, the host's requirement for fixed carbon as well as $\mathrm{N}$ is presumably the driving force for the relationship. Our results show that heterotrophic bacterial symbionts rather than cyanobionts have the genetic potential for fixing $\mathrm{N}_{2}$. Consequently, we speculate that the widespread, and somewhat counter-intuitive distribution of these large (50 to $1000 \mu \mathrm{m}$ ) species of heterotrophic dinoflagellates in the oligotrophic subtropical and tropical oceans is partly made possible by symbiont-mediated photosynthesis (Cyanobacteria) and $\mathrm{N}_{2}$ fixation (heterotrophic bacteria).

Acknowledgements. Danish Galathea expedition and the Captain of HMDS 'Væedderen', C. Smidt, and his crew are thanked for excellent assistance in connection with sampling. We thank R. A. Foster for generously providing unpublished sequence data and the anonymous reviewers for helpful comments on an earlier version of the manuscript. The project was supported by grants from Knud Højgaards Fond, Danish Natural Sciences Research Council (272-05-0333 and 272-060485 to P.J.H. and 277-05-0421 to G.H.) and Dansk Expeditions fond. The work of H.F. was supported by the Swedish Research Council FORMAS (217-2006-342 to L.R.). The present work was carried out as part of the Galathea 3 expedition under the auspices of the Danish Expedition Foundation. This is Galathea 3 contribution no. P67.

\section{LITERATURE CITED}

Alverca E, Biegala IC, Kennaway GM, Lewis J, Franca S (2002) In situ identification and localization of bacteria associated with Gyrodinium instriatum (Gymnodiniales, Dinophyceae) by electron and confocal microscopy. Eur J Phycol 37:523-530

Barberán A, Casamayor EO (2010) Global phylogenetic community structure and beta-diversity patterns in surface bacterioplankton metacommunities. Aquat Microb Ecol 59:1-10

Bergman B, Gallon JR, Rai AN, Stal LJ (1997) $\mathrm{N}_{2}$-fixation by non-heterocystous cyanobacteria. FEMS Microbiol Rev 19:139-185

Betancourt DA, Loveless TM, Brown JW, Bishop PE (2008) Characterization of diazotrophs containing Mo-independent nitrogenases, isolated from diverse natural environments. Appl Environ Microbiol 74:3471-3480
Biegala IC, Raimbault P (2008) High abundance of diazotrophic picocyanobacteria $(<3 \mu \mathrm{m})$ in a Southwest Pacific coral lagoon. Aquat Microb Ecol 51:45-53

Braun ST, Proctor LM, Zani S, Mellon MT, Zehr JP (1999) Molecular evidence for zooplankton-associated nitrogenfixing anaerobes based on amplification of the nifH gene. FEMS Microbiol Ecol 28:273-279

Capone DG, Zehr JP, Paerl HW, Bergman B, Carpenter EJ (1997) Trichodesmium, a globally significant marine cyanobacterium. Science 276:1221-1229

> Carpenter E, Montoya JP, Burns JA, Mulholland MR, Subramaniam A, Capone DG (1999) Extensive bloom of a $\mathrm{N}_{2-}$ fixing diatom/cyanobacterial association in the tropical Atlantic Ocean. Mar Ecol Prog Ser 185:273-283

> Chien YT, Zinder SH (1996) Cloning, functional organization, transcript studies, and phylogenetic analysis of the complete nitrogenase stuctural genes (nifHDK2) and associated genes in the Archaeon Methanosarcina barkeri 227. J Bacteriol 178:143-148

> Church MJ, Jenkins BD, Karl DM, Zehr JP (2005) Vertical distributions of nitrogen-fixing phylotypes at Stn ALOHA in the oligotrophic North Pacific Ocean. Aquat Microb Ecol 38:3-14

Farnelid H, Riemann L (2008) Heterotrophic $\mathrm{N}_{2}$-fixing bacteria: Overlooked in the marine nitrogen cycle? In: Couto GN (ed) Nitrogen fixation research progress. Nova Science Publishers, New York, NY, p 409-423

Foster RA, Zehr JP (2006) Characterization of diatom-cyanobacteria symbioses on the basis of nifH, hetR and 16S rRNA sequences. Environ Microbiol 8:1913-1925

> Foster RA, Carpenter EJ, Bergman B (2006a) Unicellular cyanobionts in open ocean dinoflagellates, radiolarians, and tintinnids: ultrastructure characterization and immunolocalization of phycoerythrin and nitrogenase. J Phycol 42: 453-463

Foster RA, Collier JL, Carpenter EJ (2006b) Reverse transcription PCR amplification of cyanobacterial symbiont 16S rRNA sequences from single non-photosynthetic eukaryotic marine planktonic host cells. J Phycol 42:243-250

Gordon N, Angel DL, Neorl A, Kress N, Kimor B (1994) Heterotrophic dinoflagellates with symbiotic cyanobacteria and nitrogen limitation in the Gulf of Aqaba. Mar Ecol Prog Ser 107:83-88

Goto M, Ando S, Hachisuka Y, Yoneyama T (2005) Contamination of diverse nifH and nifH-like DNA into commercial PCR primers. FEMS Microbiol Lett 246:33-38

> Hallegraeff GM, Jeffrey SW (1984) Tropical phytoplankton species and pigments of continental shelf waters of North and North-West Australia. Mar Ecol Prog Ser 20:59-74

> Hewson I, Moisander PH, Achilles KM, Carlson CA and others (2007) Characteristics of diazotrophs in surface to abyssopelagic waters of the Sargasso Sea. Aquat Microb Ecol 46:15-30

Janson S, Carpenter EJ, Bergman B (1995) Immunolabelling of phycoerythrin, ribulose 1,5-biphosphate carboxylase/ oxygenase and nitrogenase in the unicellular cyanobionts of Ornithocercus spp. (Dinophyceae). Phycologia 34: 171-176

Janson S, Wouters J, Bergman B, Carpenter EJ (1999) Host specificity in the Richelia-diatom symbiosis revealed by het $R$ gene sequence analysis. Environ Microbiol 1:431-438

Jyothibabu R, Madhu NV, Maheswaran PA, Asha Devi CR, Balasubramanian T, Nair KKC, Achuthankutty CT (2006) Environmentally-related seasonal variation in symbiotic associations of heterotrophic dinoflagellates with cyanobacteria in the western Bay of Bengal. Symbiosis 42:51-58 Langlois RJ, LaRoche J, Raab PA (2005) Diazotrophic diver- 
sity and distribution in the tropical and subtropical Atlantic Ocean. Appl Environ Microbiol 71:7910-7919

Langlois RJ, Hümmer D, La Roche J (2008) Abundances and distributions of the dominant nifH phylotypes in the Northern Atlantic Ocean. Appl Environ Microbiol 74: 1922-1931

Le Moal M, Biegala IC (2009) Diazotrophic unicellular cyanobacteria in the northwestern Mediterranean Sea: a seasonal cycle. Limnol Oceanogr 54:845-855

Loveless TM, Saah JR, Bishop PE (1999) Isolation of nitrogenfixing bacteria containing Molybdenum-independent nitrogenases from natural environments. Appl Environ Microbiol 65:4223-4226

Lucas IAN (1991) Symbionts of the tropical dinophysiales. Ophelia 33:213-224

Meeks JC, Campbell EL, Summers ML, Wong FC (2002) Cellular differentiation in the cyanobacterium Nostoc punctiforme. Arch Microbiol 178:395-403

Moisander PH, Beinart RA, Voss M, Zehr JP (2008) Diversity and abundance of diazotrophic microorganisms in the South China Sea during intermonsoon. ISME J 2:954-967

Montoya JP, Holl CM, Zehr JP, Hansen A, Villareal TA, Capone DG (2004) High rates of $\mathrm{N}_{2}$ fixation by unicellular diazotrophs in the oligotrophic Pacific Ocean. Nature 430: 1027-1031

Norris RE (1967) Algal consortisms in marine plankton. In: Krishnamurthy V (ed) Proc Seminar on Sea, Salt and Plants 1965. Central Salt and Marine Chemicals Research Institute, Bhavnagar, India. Catholic Press, Ranchi (Bihar), p 178-179

Paerl HW, Prufert LE (1987) Oxygen-poor microzones as potential sites of microbial $\mathrm{N}_{2}$ fixation in nitrogen-depleted aerobic marine waters. Appl Environ Microbiol 53:1078-1087

Riemann L, Leitet C, Pommier T, Simu K, Holmfeldt K, Larsson U, Hagström $\AA$ (2008) The native bacterioplankton community in the central Baltic Sea is influenced by freshwater bacterial species. Appl Environ Microbiol 74: 503-515

Schütt F (1895) Die Peridineen der Plankton-Expedition. Ergebnisse Plankton-Expedition der Humboldt Stiftung, Band 4. Lipsius \& Tischer, Kiel

Ruiz Sebastian C, O'Ryan C (2001) Single-cell sequencing of dinoflagellate (Dinophyceae) nuclear ribosomal genes. Mol Ecol Notes 1:329-331

Editorial responsibility: Douglas Capone,

Los Angeles, California, USA
Stal LJ, Zehr JP (2008) Cyanobacterial nitrogen fixation in the Ocean: Diversity, regulation, and ecology. In: Herrero A, Flores E (eds) The Cyanobacteria molecular biology, genomics and evolution. Caister Academic Press, Bodmin

Tamura K, Dudley J, Nei M, Kumar S (2007) MEGA4: Molecular Evolutionary Genetics Analysis (MEGA) software version 4.0. Mol Biol Evol 24:1596-1599

Tarangkoon W, Hansen G, Hansen P (2010) Spatial distribution of symbiont-bearing dinoflagellates in the Indian Ocean in relation to oceanographic regimes. Aquat Microb Ecol 58:197-213

Taylor FJR (1982) Symbioses in marine microplankton. Ann Inst Oceanogr Paris 58:61-90

> van de Werken HJG, Verhaart MRA, VanFossen AL, Willquist $\mathrm{K}$ and others (2008) Hydrogenomics of the extremely thermophilic bacterium Caldicellulosiruptor saccharolyticus. Appl Environ Microbiol 74:6720-6729

> van Niel EWJ, Budde MAW, de Haas GG, van der Wal FJ, Claassen PAM, Stams AJM (2002) Distinctive properties of high hydrogen producing extreme thermophiles, Caldicellusiruptor saccharolyticus and Thermotoga elfii. Int J Hydrogen Energy 27:1391-1398

> Zani S, Mellon MT, Collier JL, Zehr JP (2000) Expression of nifH genes in natural microbial assemblages in Lake George, New York, detected by reverse transcriptase PCR. Appl Environ Microbiol 66:3119-3124

> Zehr JP, McReynolds LA (1989) Use of degenerate oligonucleotides for amplification of the nifH gene from the marine cyanobacterium Trichodesmium thiebautii. Appl Environ Microbiol 55:2522-2526

Zehr JP, Turner PJ (2001) Nitrogen fixation: nitrogenase genes and gene expression. In: Paul JH (ed) Methods in microbiology. Academic Press, New York, NY, p 271-286

Zehr JP, Mellon MT, Zani S (1998) New nitrogen-fixing microorganisms detected in oligotrophic oceans by amplification of nitrogenase (nifH) genes. Appl Environ Microbiol 64:3444-3450

> Zehr JP, Waterbury JB, Turner PJ, Montoya JP and others (2001) Unicellular cyanobacteria fix $\mathrm{N}_{2}$ in the subtropical North Pacific Ocean. Nature 412:635-638

Z Zehr JP, Crumbliss LL, Church MJ, Omoregie EO, Jenkins BD (2003) Nitrogenase genes in PCR and RT-PCR reagents: implications for studies of diversity of functional genes. Biotechniques 35:996-1005

Submitted: November 30, 2009; Accepted: July 26, 2010

Proofs received from author(s): September 17, 2010 